\title{
Adoption process of IFRS for SMEs in Turkey: Insights from academics and accountants
}

\author{
Merve K1liça and Ali Uyar ${ }^{\mathrm{b} 1}$ \\ ${ }^{\mathrm{a}}$ Independent Scholar, Turkey; ${ }^{\mathrm{b}}$ American University of the Middle East, \\ Kuwait
}

\begin{abstract}
In 2009, the International Accounting Standards Board (IASB) issued International Financial Reporting Standards (IFRS) for Small and Medium-sized Entities (SMEs) as a simplified version of the full IFRS addressing the financial reporting needs of SMEs. Although IFRS for SMEs is still not required in this jurisdiction, Turkey was one of the first ones that have taken substantive steps towards adoption of IFRS for SMEs. The main purpose of this research is to investigate the perceptions of Turkish accountants, academicians, and auditors regarding the adoption process of IFRS for SMEs via in-depth interview methodology. The findings of the research confirmed the need for a stand-alone standard set for SMEs. The interviewees asserted that more simplification on IFRS for SMEs may hinder comparability of financial statements. While high-quality financial information will be the most important advantage of applying IFRS for SMEs, cost burdens on firms and lack of trained personnel will be the major obstacles for the implementation process.
\end{abstract}

Keywords: IFRS for SMEs; SME; interviews; qualitative study; Turkey

JEL Codes: M41, M48

\section{Introduction}

The international integration of the markets has affected the activities of multinational entities for a long time, but now is also affecting small and mediumsized entities (SMEs) (Wittsiepe, 2008). One challenging aspect of the international integration of the markets is the diversity in accounting applications of the

${ }^{1}$ Corresponding author: College of Business Administration, American University of the Middle East, Block 3, Building 1, Egaila, 15453, Kuwait. E-mail: aliuyar@ hotmail.com 
countries, which are caused by cultural, economic, social, historical, and political structures (Haverty, 2006). A common set of globally accepted financial reporting standards would decrease the diversity of financial reporting practices across world countries and would enable cross-border movement of capital and greater economic integration (Cai \& Wong, 2010). The main purpose of the International Accounting Standards Board (IASB) is to issue a common set of accounting/financial reporting standards that will enhance the comparability of financial reports across jurisdictions.

For a long time, the IASB ignored the financial reporting needs of the SMEs and focused only on the large-sized companies being accountable to public. However, most of the companies in many countries are small-sized and unlisted, and those companies have a significant incontestable role in their countries' economies. The statistics regarding the number of the SMEs also indicate this significance. For instance, within the European Union (EU), SMEs constitute at least 99\% of all enterprises (Mantzari et al., 2009), maintain nearly $65 \%$ of the employment in the private sector (Mantzari et al., 2009), and produce considerably more than 50\% of the gross domestic product (GDP) (Tudor \& Mutiu, 2008). Only in Europe, full International Financial Reporting Standards (IFRS) is required for 7,000 listed companies, while more than 7,000,000 unlisted entities mostly follow national standards, thus failing to provide a satisfactory level of international comparability (Flower, 2005). The International Financial Reporting Standard for Small and Medium-sized Entities (IFRS for SMEs) was developed and published to respond to the financial reporting needs of firms as commonly referred to SMEs, private entities, and non-publicly accountable companies (Hlaciuc et al., 2009). This was the first standard set that has taken into consideration the financial reporting needs of SMEs (Maseko \& Manyani, 2011). The main objectives of IASB in issuing IFRS for SMEs are providing a platform for SMEs to produce high-quality and globally consistent financial reports and assist them gain access to financial sources (Chand et al., 2015).

As a developing country, Turkey also needs international financial reporting standard sets (IFRS/IFRS for SMEs) to produce high-quality financial information for accessing global capital markets and international financial resources (Alp \& Ustundag, 2009). First, full set IFRS has become mandatory for only listed companies since 2005. After a while, the need for a separate standard set for SMEs became apparent. In Turkey, SMEs have a vital role in the Turkish economy by constituting $99.8 \%$ of all enterprises, maintaining $74.2 \%$ of the employment, and contributing 52.8\% of value-added (TSI, 2015). In 2010, the IFRS for SMEs was translated into Turkish as "Turkish Financial Reporting Standard for Small and Medium-sized Entities (TFRS for SMEs)", published, and included in New Turkish Commercial Code (Law No. 6102). According to this Law, SMEs would apply the IFRS for SMEs starting in 2013. Then, the Public Oversight Agency (POA) published a committee decision stating the entities which would apply the IFRS 
without mentioning the SMEs (Eskin \& Güvemli, 2015). In this regard, the IFRS for SMEs still is not required for Turkish SMEs and they continue to use Turkish national Generally Accepted Accounting Principles (GAAP) (the uniform chart of accounts). Turkey is a unique setting since it is an early adopter of IFRS for SMEs but still does not require the use of this standard set. Although IFRS for SMEs is not still required for SMEs, Turkey was considered to be one of the first jurisdictions that have taken several steps to adopt the IFRS for SMEs.

The primary purpose of this paper is to provide an ex-ante study on the issues about the adoption process of IFRS for SMEs in Turkey by interviewing prominent accounting academics and accountants. Their insights will provide some guidelines to the regulators and SMEs. They openly declared their opinions regarding the scope of IFRS for SMEs, perceived advantages, disadvantages, difficulties, and other issues as highlighted in the findings and discussion section. Thus, we hope that the results provide important implications for other countries as well. Further, we extensively review the relevant literature to synthesize the findings at the international level in order to discuss the Turkish case.

For this paper we have conducted interviews with accounting professionals who are quite knowledgeable about the issues regarding the adoption process of the IFRS for SMEs in Turkey. This study aims at identifying the current financial reporting practices of the SMEs, to explore whether the IFRS for SMEs is simplified enough for SMEs, to investigate whether the IFRS for SMEs is suitable for micro-entities, to examine perceived advantages, disadvantages, implementation challenges and obstacles of the adoption process, and to determine what should be done to accelerate the adoption process.

The findings of the research indicated that (1) SMEs generally perform financial reporting for only tax purposes; (2) the interviewees confirmed the need for a stand-alone accounting standard set for SMEs; (3) entities may be exempted from the scope of IFRS for SMEs according to another criterion rather than being a micro-entity; (4) more simplification on IFRS for SMEs may hinder comparability of financial statements; (5) high-quality financial information will be the most important advantage of applying IFRS for SMEs; and (6) cost burdens on entities and lack of trained personnel are the major obstacles for the implementation process.

This research contributes the literature in several ways. First, it enhances the growing body of literature about the IFRS for SMEs by examining the perceptions and views of the accountant practitioners, academics, and auditors. Second, it bases the findings of the research on data gathered through the in-depth interviews. Unlike prior research based predominantly on questionnaires (see, for example, Van Wyk \& Rossouw, 2009; Siam \& Rahahleh, 2010; Bunea et al., 2012; Uyar \& Güngörmüş, 2013; Kılıç et al., 2014), it undertakes a qualitative methodology, 
namely interview to learn the opinions of professionals in depth. Third, it presents the experiences of an early adopter country case. Although IFRS for SMEs is not still required for SMEs in the country, Turkey was considered to be one of the first countries that took some steps to adopt the IFRS for SMEs. The case of Turkey signifies the challenges and obstacles in the adoption process of the standard set for SMEs.

The remainder of the article is structured as follows. The next section gives a brief explanation regarding the emergence of the IFRS for SMEs. The third section explains the regulatory environment in Turkey. The fourth section presents literature review and the research questions. The fifth section summarizes the methodology and data, followed by the sixth section which reports the research findings. Finally, the seventh section concludes the paper.

\section{Emergence of the IFRS for SMEs}

A predominant body of research on accounting standards focuses on the reporting needs of publicly listed companies and global capital markets. In fact, SMEs play a significant role in economies of the countries by creating new employment opportunities (Al-Mahrouq, 2010; Perera \& Chand, 2015), alleviating the unemployment problems (Siam \& Rahahleh, 2010), sustaining economic growth (Beck \& Demirguc-Kunt, 2006), and attracting foreign funds (Al-Mahrouq, 2010). SMEs are financially more constrained compared to larger entities due to inadequate financial resources, especially in developing countries (Beck \& Demirguc-Kunt, 2006; Beck et al., 2008). The adoption of a universally accepted set of financial reporting standards would enhance the financing opportunities for the SMEs.

In prior literature, there are some arguments suggesting a unified common set of standards cannot respond to the financial reporting needs of the listed and unlisted companies. First, the financial statement users of public companies are more diversified than SMEs (Bunea et $a l ., 2012$ ) as their ownership structure is more diffused. The type of information needed by a small business also differs from that of a large company (Stainbank, 2008). In addition, SMEs have fewer resources and limited or no access to capital markets compared with large listed entities (Maseko \& Manyani, 2011).

In 2003, the IASB started building international accounting standards for SMEs to meet the demand for a simple, high-quality, understandable, and enforceable standard set that will be suitable for SMEs worldwide (Müllerová et al., 2010). Subsequently, the IASB proposed a discussion paper in 2004, "Preliminary views on accounting for small and medium entities", concerning this need. In 2005, the IASB published a staff questionnaire on possible recognition and measurement 
modifications for small and medium entities to determine the topics that should be discussed at meetings with the financial statement users and preparers (Stainbank, 2008). In February 2007, the "Exposure draft of proposed international financial reporting standard for small and medium-sized entities" was published with a comment period running up to October 2007 (Fearnley \& Hines, 2007). Finally, in July 2009, "IFRS for SMEs" was issued as a new standard set for SMEs (Albu et al., 2010). After the initial comprehensive review of the standard, in 2013, the IASB has issued the Exposure Draft on the proposed amendments to the IFRS for SMEs, including some clarifications and supportive guidance (Perera \& Chand, 2015). Then, in late 2015, a revised version of IFRS for SMEs was published including further amendments.

The IFRS for SMEs consists of simplified and condensed accounting principles based on the full set of IFRS. It is intended to be applicable to all entities and businesses that do not have public accountability and publish general purpose financial statements. The SME definition of IASB does not contain any significant quantified measurements. Therefore, local jurisdictions will determine and enforce specific criteria, such as quantitative measurements, to establish whether an entity will use the IFRS for SMEs or not. The IASB underlines that IFRS for SMEs will be suitable for entities that do not have public accountability and constitute nearly $95 \%$ of the entities all over the world (Tudor \& Mutiu, 2008). Besides, the IASB acknowledges that the regulators and standard-setting authorities of each country would make decisions about which entities would use IFRS for SMEs (Daly, 2009).

In 2010, the European Commission (EC) suggested the adoption of the IFRS for SMEs and decided to seek the opinion of the EU financial statement users on this issue (Bohusova et al., 2012). In Europe, different jurisdictions held different opinions regarding the adoption of the IFRS for SMEs. The significant link between taxation and capital maintenance rules in certain EU member countries makes the application of IFRS for SMEs burdensome for entities by modifying existing requirements or duplicating reporting systems (Kaya \& Koch, 2015). For instance, Austria, Belgium, Italy, Finland, France, and Germany have become the major opponents of the IFRS for SMEs (Bohusova \& Blaskova, 2012). The most significant supporters of the IFRS for SMEs in the EU are the United Kingdom and Ireland where regulatory forces between tax accounting and financial accounting are minimal or non-exist (Bohusova et al., 2012; Kaya \& Koch, 2015). While the developed nations that have their own accounting bodies or local GAAP have generally ignored the IFRS for SMEs, a significant amount of developing nations have accepted and applied it. For instance, South Africa became the first country in the world which approved the IFRS for SMEs (Van Wyk \& Rossouw, 2009). Furthermore, governments, especially in countries that have limited domestic financial resources, want their domestic businesses to expand internationally and to access foreign financial resources (Walton, 2011). The decision to adopt IFRS for 
SMEs enables a developing country to signal to creditors and international investors that it is willing to apply a high-quality and internationally accepted financial reporting standards fostering inflows of capital from other jurisdictions (Chand et al., 2015; Kaya \& Koch, 2015). In order to be competitive in international capital markets, regulators of emerging nations are more willing to take timely measures to harmonize their financial reporting practices with globally accepted financial reporting standards. Based on the IASB (2017) data, 84 jurisdictions in total have adopted or permitted the use of IFRS for SMEs most of which are developing countries such as Argentina, Azerbaijan, Bahrain, Bangladesh, Brazil, Jordan, Malaysia, Philippines, Singapore, Saudi Arabia, Uruguay, Venezuela, and Yemen.

\section{The Turkish context}

Turkish regulatory bodies are following the latest developments in financial reporting standards to maintain the compliance with EU Accounting Directives as the country seeks for EU full membership. There were two effective bodies in Turkey to develop financial reporting standards: the Turkish Capital Market Board (CMB) and the Turkish Accounting Standards Board (TASB). In 2011, the TASB was replaced by a new institution called the POA. The POA has become the unique authority to designate and publish financial reporting standards in Turkey.

The convergence of Turkey to IFRS started in November 2003 by the communiqué of CMB for listed companies to adopt International Accounting Standards (IAS) (Poroy Arsoy \& Sipahi, 2007). Until that time, financial reporting had been considered as a tool for calculating tax rather than for evaluating the financial position of entities (Akyüz et al., 2006). The communiqué that was issued by the CMB was one of the most important steps towards harmonizing the existing financial reporting practices with international standards (Poroy Arsoy \& Sipahi, 2007). When the EU declared that the IFRS would be effective from 2005, Turkey also promulgated this set for the use of listed entities (Koc Yalkin et al., 2006).

In subsequent years, a need for a separate standard set for SMEs was also recognized in Turkey. The TASB formed a working commission to discuss and develop financial reporting standards for SMEs (Alp \& Ustundag, 2009). As a result, the IFRS for SMEs was issued in the Official Gazette, dated 1st November 2010, numbered 27746 and included in the content of Turkey's New Commercial Code (Law No. 6102). This Law mandated that SMEs must keep their accounts and prepare their financial statements in accordance with the IFRS for SMEs starting from 1st January 2013 (Y1ld1z \& Eskin, 2012). However, some discussions have emerged regarding several amendments such as exclusion of micro-entities from the scope of the standard set and issuance of additional guidance (Albu et al., 2013). Subsequently, the Law on the amendments (Law No. 6335) to the New 
Commercial Code was published in the Official Gazette, dated 30th June 2012, numbered 28339. Pursuant to this amendment, the SMEs were required to prepare only their financial statements compatible with the IFRS for SMEs and continue to keep their accounts according to the Tax Law (Law no. 213) (Eskin \& Güvemli, 2015). Then, the POA published a committee decision in the Official Gazette, dated 17th November 2012, numbered 28470, which declared the entities which would apply the IFRS without mentioning the SMEs (Eskin \& Güvemli, 2015). Hence, the IFRS for SMEs still is not required in Turkey and SMEs continue to use Turkish national GAAP (the uniform chart of accounts).

\section{Literature review}

Since the full set IFRS was the prior project of the IASB, a significant number of studies has dealt with this set (see, for example, Dumontier \& Raffournier, 1998; El-Gazzar et al., 1999; Murphy, 1999; Georgiou, 2010; Iatridis \& Rouvolis, 2010; Bahadir et al., 2016; Uyar et al., 2016). After the issuance of the IFRS for SMEs, a considerable number of studies have investigated the perceptions and views of the accounting practitioners about this standard, especially in emerging countries (see, for example, Van Wyk \& Rossouw, 2009; Siam \& Rahahleh, 2010; Albu et al., 2013; Uyar \& Güngörmüş, 2013; Kılıç et al., 2014).

Current accounting environment in SMEs is one of the issues that will impact the implementation process of IFRS for SMEs. For instance, Albu et al. (2010) examine the issues related to a possible implementation of IFRS for SMEs in Romania through in-depth interviews. They determined that the State is the main user of the financial statements of the SMEs and other users are skeptical about the reliability of provided information. Further, Albu et al. (2013) explored the perceptions of several stakeholders regarding IFRS for SMEs from different emerging countries, namely the Czech Republic, Hungary, Romania, and Turkey. They underlined that there is a strong link between accounting and taxation for SMEs in emerging countries, and the State as the main financial statement user of the SMEs, may hinder the benefits of IFRS for SMEs by focusing on accounting and tax regulations.

The need for a separate standard set for SMEs and usability of the IFRS for SMEs for micro-sized entities are also explored by prior research. For instance, Bunea et al. (2012) investigated the views of the accounting professionals about the IFRS for SMEs in Romania. Their findings showed that a significant percentage of the respondents suggest more simplification on the current reporting system for a group of entities which will be determined according to criteria, such as turnover, number of employees, and total assets. Regarding this issue, Albu (2013) investigated whether the size is relevant in determining the scope of the IFRS for SMEs in Romania. The findings of the study denoted that using only size as a 
criterion for setting the scope of the IFRS for SMEs may cause the exemption of a significant amount of companies and therefore may lead to compliance issues. Van Wyk and Rossouw (2009) revealed that South-African accounting practitioners are skeptical about whether the IFRS for SMEs is useful for the micro-entities and suggested the development of a simplified tier of standards for those companies. Similarly, Aboagye-Othchere and Agbeibor (2012) explored the suitability of the IFRS for SMEs for small entities in Ghana. They determined that small businesses, whether micro-entities or SMEs, have limited need for the IFRS for SMEs due to their low level of international activities. They also suggested the submission of a simpler tier of IFRS for SMEs addressing the reporting needs of small businesses. Chand et al. (2015) also determined that standard-setters in Fiji suggest some exemptions for micro-entities to make IFRS for SMEs more cost effective for them.

Since the IFRS for SMEs was promulgated to be adopted by SMEs in 2012, the research regarding Turkey presents findings about the preparedness and knowledge level of several groups, such as accounting practitioners, auditors, and entities. For example, Uyar and Güngörmüş (2013) investigated the knowledge level and perceptions of Turkish accounting practitioners regarding the IFRS for SMEs. They determined that proponents of stand-alone IFRS for SMEs are significantly higher than its opponents and most of respondents have little knowledge of IFRS. Kılıç et al. (2014) also explored the knowledge level, preparedness, and perception of Turkish accounting practitioners about the IFRS for SMEs. Their findings reveal that most of the respondents made some preparations and have a moderate level of knowledge regarding this set. Kilıç et al. (2016) analyzed the preparedness level of Turkish SMEs via a questionnaire survey. They found that most of the SMEs have not made any preparation for the IFRS for SMEs.

The prior findings presented the perceived advantages of the IFRS for SMEs as enhanced comparability, reliability, and transparency of financial statements (Siam \& Rahahleh, 2010; Albu et al., 2013; Uyar \& Güngörmüş, 2013; Kılıç et al., 2014), effective financial reporting (Kılıç et al., 2014), increase in accessing to national and international financial sources (Uyar \& Güngörmüş, 2013; Kılıç et al., 2014), improvement of the national business environment (Albu et al., 2013), enhanced efficiency of cross-border activities (Uyar \& Güngörmüss, 2013), ease of rating SMEs by credit rating agencies (Uyar \& Güngörmüş, 2013). Besides, several disadvantages and challenges of the implementation of the IFRS for SMEs adoption process were also reported by the researchers such as lack of trained personnel (Uyar \& Güngörmüş, 2013; Kılıç et al., 2014), difficulty in understanding the complex and detailed nature of standards (Quagli \& Paoloni, 2012; Kılıç et al., 2014), lack of knowledge (Kaytmaz Balsari \& Varan, 2014), costly adoption process (Kilıç et al., 2014; Chand et al., 2015), costs arising from possible duplication of reporting (Albu et al., 2013), and training costs (Albu et al., 2013). 


\section{Methodology and data}

The methodology of the study is qualitative such that we conducted interviews with professionals in the field of accounting. Six interviews took a period of five months from February to June 2012 to develop the understanding of issues regarding IFRS for SMEs. Though the interviews were conducted in 2012, the findings are still relevant for today's environment since the basic situation relating to the IFRS for SMEs adoption process has not undergone a significant change during this period of time. More, they were conducted in a period where the discussion about the adoption of the standard was very vivid and are thus very informed and informative. Further, we reviewed the relevant literature, legislation, local policy and guidelines, and professional articles to understand more comprehensively the IFRS for SMEs adoption process. Mainly, we sought answers to the following research questions formulated based on the literature review provided in the preceding sections:

$R Q 1$ : Why do Turkish SMEs need a separate standard set?

$R Q$ 2: Should IFRS for SMEs be simplified more for the use of Turkish SMEs?

$R Q 3$ : What might be the potential advantages and disadvantages of the IFRS for SMEs adoption in Turkey?

$R Q 4$ : What might be the potential challenges that firms may face in case IFRS for SMEs adoption in Turkey?

During the interviews, we have taken notes and recorded interviews with the permission of interviewees. We guaranteed respondent anonymity and to maintain the anonymity of the interviewees, we coded the interviewees as Interviewee 1, Interviewee 2, and so on in the discussion. Originally, we carried out interviews in Turkish, and then we translated them into English to perform the analysis. In order to capture different perspectives, we selected the respondents from auditors, accountants, and academicians who were quite knowledgeable with regard to the research goals and standard context. We present the profiles of the respondents in Appendix A.

All the interview questions were open-ended and unstructured to allow the participants to provide their opinions through a "free-flowing" discussion. These unstructured questions were supported by supplementary questions during the interviews. Open-ended questions allow the respondents to expand on their opinions about the subjects covered in the interview. Also, the open-ended and unstructured format encourages the interviewees to speak broadly and deeply about the issues (Marwata, 2006). We based the interviews on research questions derived from the relevant literature. The order in which the questions were presented was altered during the interviews to keep the underlying aim of the interviews. The length of the interviews was between 30 and 90 minutes. We provide the list of interview questions in Appendix B. 


\section{Research findings and discussion}

\subsection{Development IFRS for SMEs in Turkey}

\subsubsection{Financial reporting in SMEs}

All of the interviewees indicated that Turkish SMEs prepare financial statements for tax purposes. Interviewee 1 stated that SMEs make financial reporting for external constituencies rather than internal decision making processes in Turkey. In addition, Interviewee 4 and Interviewee 5 specified that current financial statements of Turkish SMEs do not present their actual position because they are created only for tax purposes. This type of financial reporting deteriorates the quality of the information disclosed, and hence decreases the credibility of financial statements. The findings of this study are in compliance with prior research indicating that SMEs generally prepare financial statements for only tax purposes (Maingot \& Zeghal, 2006; Van Wyk \& Rossouw, 2009; Müllerová et al., 2010; Maseko \& Manyani, 2011; Albu, 2013; Albu et al., 2013). For instance, Tudor \& Mutiu, (2008) stated that financial statement users of SMEs focus on generally short-term cash flows, liquidity, and solvency of the company. Hence, SMEs perform financial reporting generally for tax purposes in concordance with the regulations of the jurisdictions in which they operate (Christie et al., 2010).

\subsubsection{Suitability of IFRS for SMEs for micro-entities}

Most of the interviewees stated that a number of micro-entities may be exempted from the IFRS for SMEs according to criteria other than being a micro-entity, except for Interviewee 1 . He asserted that micro-entities most probably will be exempted from IFRS for SMEs adoption process because it is doubtful whether this standard set will provide expected benefits to them. On the other hand, Interviewee 2 suggested that the entities which cannot cope with independent auditing costs may be exempted from the mandatory adoption process. Furthermore, Interviewee 3 and 4 stated that entities which employ one or two people may not use the IFRS for SMEs. In addition, Interviewee 3 indicated that nearly $90 \%$ of companies are micro-sized entities, which employ less than 10 people, in Turkey. If all of those entities are exempted from this standard set, there will be very few companies that will apply the IFRS for SMEs. Further, according to Interviewee 6, use of globally understandable financial reporting standards may enhance the financing opportunities of micro-entities and hence those entities should not be exempted from the scope of IFRS for SMEs. 


\subsubsection{The effects of the IFRS for SMEs on stakeholders}

There will be some possible effects of the IFRS for SMEs on several stakeholders. The interviewees indicated that the adoption of this standard will be advantageous for all of the stakeholder groups. Interviewees 4 and 5 stated that the IFRS for SMEs will minimize the risk of credit institutions because they can receive true and fair information. Interviewee 1 revealed that auditors and the minority shareholders will also obtain true information about the activities of the entities and gain benefit from the application of this standard set. In addition, Interviewee 2 asserted that the State will be the most advantageous party from the adoption of IFRS for SMEs by obtaining true information from all of the companies with a common standard set. Therefore, it is expected that many stakeholders will benefit from the adoption process of the IFRS for SMEs in Turkey, including auditors, creditors, accountants, banks, the State, and minority shareholders.

\subsubsection{The acceleration of the adoption process for the IFRS for SMEs}

There may be several precautions that may be performed for the acceleration of the adoption process of the IFRS for SMEs. Most of the interviewees highlighted that training may have a vital role in the acceleration of the adoption process. Interviewee 1, 2, 4 and 5 stated that the adoption process can be accelerated through more trainings, seminars, and symposiums about the IFRS for SMEs. According to Interviewee 3 and 6, the official announcement should be made as soon as possible and further postponements must be avoided to accelerate the adoption process of the IFRS for SMEs in Turkey. In this vein, most of the interviewees underlined that as the accountants and auditors take more training, they will be more aware of the importance of this standard, which in turn, will increase awareness of the related parties for the IFRS for SMEs and quicken the adoption process.

\subsection{Need for a separate standard for SMEs and issue of simplification}

The IASB focused on entities that have about 50 employees when determining the content of the IFRS for SMEs. This 50-employee guideline is not intended to be a quantified size criterion, but a basis to decide the kinds of transactions, events, and conditions that should be included in or excluded from the proposed standard set (Pacter, 2009). According to the IASB, every local jurisdiction will determine and enforce specific criteria, such as quantitative measurements, to decide whether an entity will use the IFRS for SMEs or not. For instance, Van Wyk and Roussouw (2009) determined that the benchmark of 50-employee is considered to be too high for South Africa. Interviewee 2, 4 and 5 stated that the full set of IFRS is difficult to apply for Turkish SMEs due to lack of experienced personnel and restricted sources. The full set of IFRS necessitates more disclosures and financial information which would increase financial reporting costs of small entities. 
Furthermore, Interviewee 1 voiced the need for another standard set for SMEs to cure the current problems in the financial reporting system and stated that:

"The financial reporting needs of the SMEs are different from large businesses. The full set of IFRS is more detailed and comprehensive than the IFRS for SMEs. So, the IFRS for SMEs has been simplified according to the financial reporting needs of those entities".

Prior research is also debating the issue of why there is a need for a separate standard set for SMEs. According to researchers, there are significant differences between the financial reporting practices of listed companies and SMEs which necessitate a separate standard set for SMEs. First, the SMEs have very few financial statement users compared to large and publicly listed companies (Pacter, 2009). The financial statement users of large listed companies differ from those of small unlisted companies not only in number, but also with respect to their nature and information needs (Mantzari et al., 2009). In this vein, two standards have been developed by the IASB: the full set of IFRS and the IFRS for SMEs, for listed entities and SMEs, respectively. As the accounting rules become more complex, doubts about whether one accounting model fits all small and large businesses increase (Fearnley \& Hines, 2007).

\subsection{Simplification of the full set of IFRS}

One of the critical questions is whether the IFRS for SMEs has been simplified enough for the use of SMEs. Interviewee 2 highlighted the possible impact of the simplification on measurement principles and stated that:

"The standard set for the SMEs should not be simplified any more. More simplification will affect measurement principles and hinder the expected comparability of the financial statements of the entities. The independent audit can be performed more effectively with a common set of standards. If this set is simplified more for small entities, the measurement will be a problem. The reduction of the number of the pages is not an important issue, the important thing is the change of mindset. The purpose of both the full set of IFRS and the IFRS for SMEs is to make measurement more comparable among entities all over the world. To make accounts as comparable as possible, the measurement principle should be the same in both the full set of IFRS and the IFRS for SMEs".

In addition, Interviewee 4 declared that:

"The existing set should be applied in its current format. The items which are difficult to apply have already been exempted from the set. The current items in the IFRS for SMEs are applicable to those entities. Hence, the IFRS for SMEs should not be simplified any more".

Interviewee 1 asserted that:

"The first simplification of the IFRS for SMEs was not at the expected level. Then, the IASB has made some further changes in the full set of IFRS for more simplification and published the existing set for SMEs. The current standard set is more simplified than the first draft, but applicants still must know the main 
terminology, measurement and recognition principles, arguments, and discussions in the full set of IFRS to apply the IFRS for SMEs properly".

Moreover, Interviewee 6 clarified the issue of simplification as follows:

"this set will be easy to apply for the entities in Europe because their current reporting system is similar to the system which is proposed by the IASB. In my opinion, the IFRS for SMEs is very different from the current financial reporting system in Turkey. Despite all this, the IFRS for SMEs should not be simplified yet more".

In conclusion, most of the interviewees denoted that the IFRS for SMEs should not be simplified any more to achieve the expected goals of the adoption process. Although Interviewees 1 and 6 are not in favor of any simplification, they stated that the current standard set is still difficult for SMEs.

\subsection{Advantages, disadvantages, and challenges of implementing IFRS for SMEs}

\subsubsection{Advantages of implementing IFRS for SMEs}

Interviewee 1, 3, 4 and 5 stated that the IFRS for SMEs will enable true and fair information, and therefore will enhance the quality and transparency of financial reporting in Turkey. Several prior researchers also pointed that advantage of a common set of standards to the financial statement users (El-Gazzar et al., 1999; Joshi \& Ramadhan, 2002; Epstein \& Jermakowicz, 2007; Ankarath et al., 2010). For instance, Zeghal and Mhedhbi (2006) indicated that the creation of high-quality information will be maintained with internationally accepted and recognized financial reporting standards. There are several discussions about how this highquality information will be a result of a common set of standards. The results of those discussions suggest that mandatory adoption of the international reporting standards instead of national ones will lead to significant benefits in terms of financial information quality by increasing transparency, enhancing the level of disclosure, and improving the comparability of financial statements (Jeanjean \& Stolowy, 2008). The Securities and Exchange Commission (SEC) (2000) also reveals that "high quality information will be provided with three elements: comparability, transparency, and full disclosure."

Further, Interviewees 1, 3, and 4 also emphasized the importance of the IFRS for SMEs in accessing international financial resources. This finding is incompliance with prior research (El-Gazzar et al., 1999; Joshi \& Ramadhan, 2002; Ankarath et al., 2010; Uyar et al., 2016).

There are other advantages of the adoption of internationally acceptable reporting standards which were denoted by the interviewees. For instance, Interviewee 2 
stated that the adoption of IFRS for SMEs will decrease auditing costs because independent auditing process will be performed in a shorter span of time with a fewer personnel. Furthermore, according to the Interviewee 6, the IFRS for SMEs will enhance the financial sustainability of Turkish SMEs.

\subsubsection{Disadvantages of implementing IFRS for SMEs}

Interviewee 1, 4, and 6 emphasized that the costs related to the adoption of IFRS for SMEs will be one of the most important disadvantages, especially in the shortrun. In contrary, other interviewees denoted that there will not be any disadvantages of adopting this standard set. In compliance with our results, prior research indicated that possible costs related to the application of this standard seem to be the most important disadvantage of the adoption process (Albu et al., 2013; K1lıç et al., 2013; Uyar and Güngörmüş, 2013; K1lıç et al., 2014).

\subsubsection{Challenges of implementing IFRS for SMEs}

Some challenges and obstacles may be encountered by entities in the first application of the IFRS for SMEs and during the adoption process as lack of trained personnel, interpretation difficulties, and language issue. All of the interviewees stated that lack of trained personnel will be the most important challenge for SMEs in the adoption process. The lack of IFRS education, knowledge, and training at the university, business enterprise, and accountancy bodies will be critical and vital challenges in the IFRS for SMEs adoption process. Interviewee 3 and 4 indicated that interpretation problem will emerge while applying the IFRS for SMEs, especially in the early years of the adoption process. Zeff (2007) also denoted that there are some problems caused by interpretation, because interpretation plays a very important role in the effective application of standards and therefore in the achievement of comparability. The principle-based nature of the IFRS and the need for an extensive use of professional judgment are likely to cause inconsistent interpretations and differences in applications (Hora et al., 1997; Alali \& Cao, 2010; Chand et al., 2010; Hellmann et al., 2010).

The summary of the interviews is presented in Table 1.

\subsection{Current status of IFRS for SMEs adoption process}

In 2010, the IFRS for SMEs was published and included in the content of Turkish New Commercial Code (Law No. 6102) to respond the financial reporting needs of SMEs. The promulgation of this Law was considered to be one of the most 
important steps towards adopting the IFRS for SMEs. Turkey became one of the earlier adopters of IFRS for SMEs in the world by mandating the use of this standard through national regulations. Initially, Turkey planned to implement IFRS for SMEs starting in 2013, then postponed the application to 2014 (K1lıç et al., 2014). In 2012, the POA published a committee decision which declared the entities which would apply the IFRS without mentioning the SMEs. Therefore, the application of IFRS for SMEs has been abolished and SMEs continue to use Turkish national GAAP (the uniform chart of accounts).

The principal question is why Turkey failed to achieve its intended objectives regarding adoption process of IFRS for SMEs. Various reasons might be pointed out to answer this question, such as significant differences between current national regulations and proposed standards, lack of trained personnel, concerns about adaptation and application costs, and ambiguity about the scope of the IFRS for SMEs.

Our interviewees revealed that since the main user of the financial statements produced by the SMEs is the State, those entities carry out financial reporting only for tax purposes in Turkey like in many other jurisdictions. Confirming our results, many prior findings reported that Turkish SMEs prepare their financial statements for only tax reporting in accordance with Turkish Tax Legislation (see, for example, Poroy Arsoy \& Sipahi, 2007; Köse, 2009; Atik, 2010; Şensoy \& Perek, 2010). There are major differences among Turkish Tax Legislation and IFRS for SMEs. For instance, recognition and measurement principles required by IFRS for SMEs will significantly differ from Turkish Tax Legislation (Şensoy \& Perek, 2010). The significant differences between the current national accounting regulations and proposed financial reporting standards might cause the phenomenon of resistance to change.

Our interviews indicated that one of the most important challenges facing the SMEs for the adoption process of IFRS for SMEs was the lack of trained personnel. Supporting this finding, prior research showed that there was a lack of preparation among accountant professionals and SMEs. For instance, Albu et al. (2013) determined that accountant professionals were not properly prepared for the IFRS for SMEs application to cope with the challenges that would occur during the adoption process. Similarly, Kilıç et al. (2016) found that most entities have not made any preparation for the adoption of IFRS for SMEs. Uyar and Güngörmüş (2013) also determined that majority of accountants had little knowledge of IFRS. K1lıc et al. (2014) reported that although the accountant professionals were aware of IFRS for SMEs adoption process, they had a moderate level of information related with this standard set. Further, Alp and Ustundag (2009) stated that only very few professional accountants had a detailed knowledge of financial reporting standards, and these standards require 
proficiency on application phase. In this regard, the application of new standards will result in the recruitment of new employees or re-training of the existing employees (Hellmann et al., 2010). Since SMEs have insufficient resources to train and educate staff on the application of the IFRS (Jones \& Finley, 2011), lack of trained personnel seems to be a major obstacle to adoption of IFRS for SMEs in Turkey.

Concerns about the application and adaptation costs are also considered to be important challenges for the IFRS for SMEs adoption process. Although the adoption of the IFRS for SMEs is less costly compared with the adoption of the full set of IFRS, adoption costs remain the main disadvantage because certain fixed conversion or implementation costs will be burdensome for small entities (Ballas et al., 2010). Some of those IFRS adoption costs can be summarized as: the cost of continuous training of accountants and staff in all aspects of all standards (Barker \& Noonan, 1996, Ballas et al., 2010; Herman, 2010; Rezaee et al., 2010; Albu et al., 2013); the significant investment costs that will be made in new accounting software (Winney et al., 2010); the cost of collecting, summarizing, and computing the figures and information to be disclosed (Barker \& Noonan, 1996); the cost of implementing a dual accounting system arising from the application of standards for financial reporting purposes and also from the application of tax legislation (Ballas et al., 2010; Albu et al., 2013); the cost of developing local regulatory and enforcement mechanisms (Hodgdon et al., 2009).

Another challenge regarding the IFRS for SMEs adoption process was the ambiguity about its scope. SMEs are not a homogenous group; some entities have fewer than ten employees which are called micro-entities, and it is arguable whether the IFRS for SMEs is suitable for them. Although the IFRS for SMEs is a simplified version of full IFRS, the application of this set is still appears to be burdensome for SMEs, especially for micro-entities (Perera \& Chand, 2015). Majority of the respondents indicated that if all of the micro-entities, representing nearly $90 \%$ of total companies in Turkey, are excluded from the scope of the IFRS for SMEs, there will be very few companies that would apply this set. There are also several suggestions proposing to publish a simplified tier of IFRS for SMEs for the reporting needs of micro-entities. Such a simpler tier of accounting standards may decrease the costs of those entities, but would not provide adequate information about the entity's financial position, performance, and cash flows in making decisions (Pacter, 2009).

Adopting IFRS for SMEs appears to be challenging for Turkey due to reasons discussed above. Turkey is now more concerned with the issue of the Local Financial Reporting Framework (LFRF) for the entities which are not in the scope of full IFRS but obliged to independent auditing. Turkey, as an EU full membership candidate, follows and considers the EU Accounting Directives. The POA has started to study on LFRF which is compatible with EU Accounting 
Directive (2013/34/EU) since 2014 and published a draft in 2015. The LFRF was prepared by considering EU regulations, international financial reporting standards (IFRS/IFRS for SMEs), FRS 102 of UK and Republic of Ireland, and national accounting regulations (Öztürk, 2017). After the issuance of LFRF, the entities which are not obliged to independent auditing will continue to apply Turkish national GAAP. Hence, there will be various tiers of financial reporting: full IFRS, LFRF, and Turkish national GAAP (Kaya \& Türegün, 2017). In a workshop which aimed to discuss issues relating to LFRF, academicians suggested the use of LFRF by all non-publicly accountable entities with several exemptions (i.e. preparing a cash flow statement and a statement of changes in equity, reporting deferred taxes, and disclosing financial footnotes) for SMEs (Öztürk, 2017). 
Table 1. Summary of the interviews

\begin{tabular}{|c|c|c|c|c|c|c|c|}
\hline 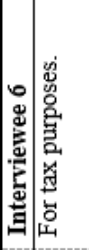 & 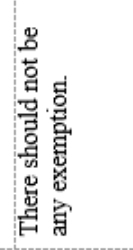 & 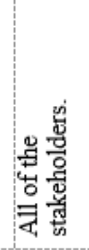 & 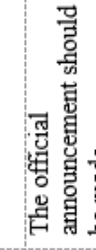 & 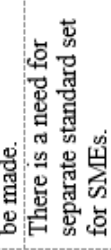 & 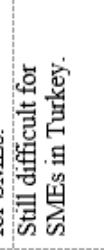 & 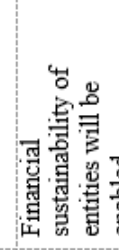 & 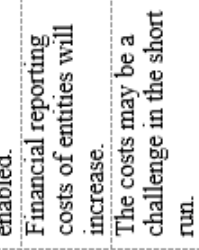 \\
\hline 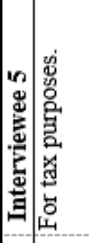 & 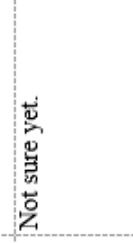 & 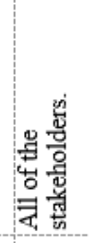 & 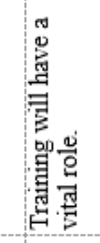 & 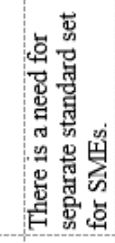 & & 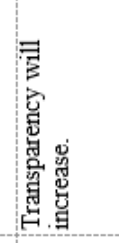 & 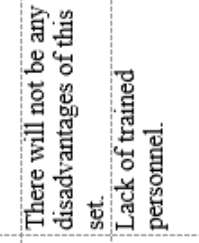 \\
\hline 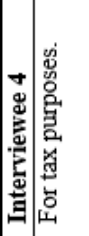 & 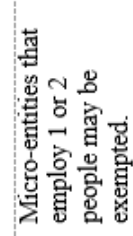 & & 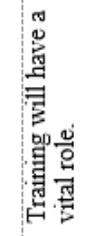 & 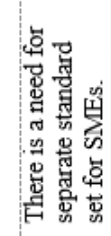 & 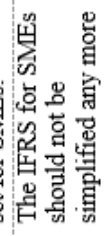 & 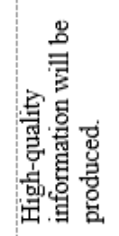 & 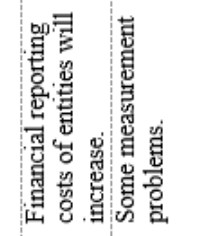 \\
\hline 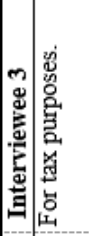 & 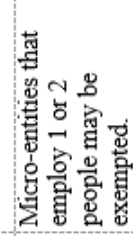 & & 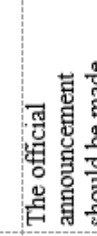 & 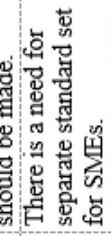 & 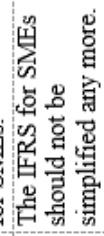 & 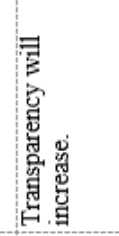 & 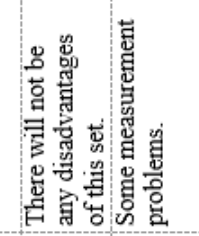 \\
\hline 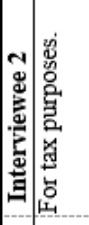 & 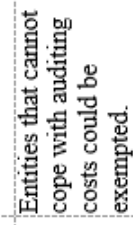 & 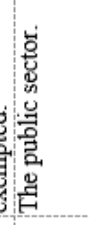 & 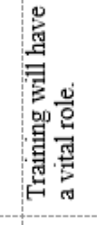 & 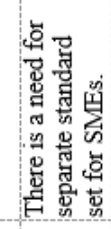 & 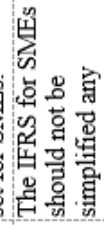 & 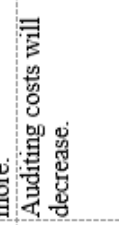 & 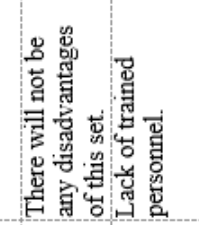 \\
\hline 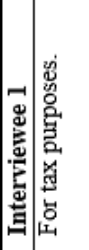 & 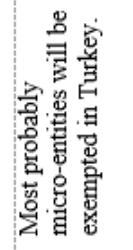 & 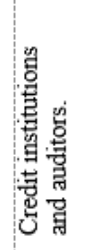 & 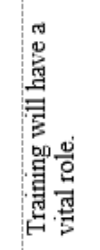 & 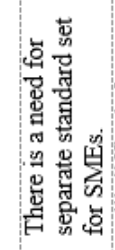 & 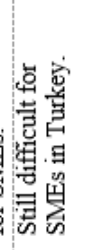 & 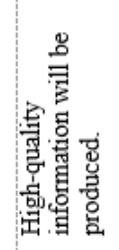 & 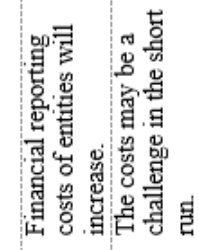 \\
\hline 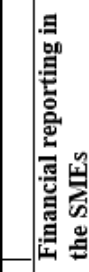 & 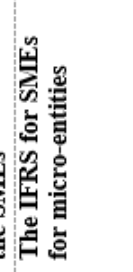 & 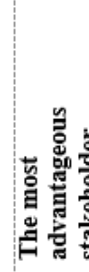 & 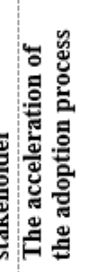 & 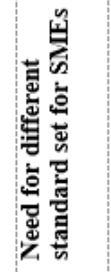 & 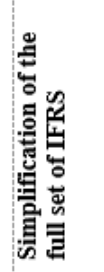 & 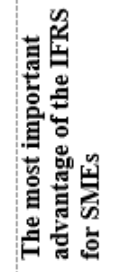 & 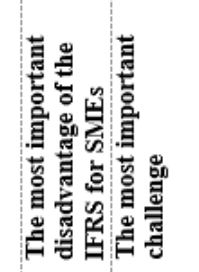 \\
\hline
\end{tabular}




\section{Conclusions}

This research investigated the views of accountants, auditors, and academicians regarding the adoption process of the IFRS for SMEs in Turkey through in-depth interviews. The interviewees provided insights into the several issues about the IFRS for SMEs. Since the application of the IFRS SMEs is not still required in Turkey, this research presents ex-ante findings regarding the issues about the IFRS for SMEs adoption process.

Since the financial reporting is carried out for only tax purposes in SMEs, some revisions have been needed to allow more effective communication between SMEs and their financial statement users. The IFRS for SMEs would be useful to maintain this effective communication between an entity and its stakeholder groups, including minority shareholders, banks, suppliers, creditors, and international credit institutions. Findings of the interviews reported the need for a separate financial reporting standard set for SMEs due to the complexity and costly adoption of the full set of IFRS. In this sense, our interviewees reported that a stand-alone standard set for the SMEs should be implemented because a unique common standard set would not respond the needs of both of listed and unlisted companies. In addition, interviews revealed that more simplification on the IFRS for SMEs may affect measurement and recognition principles and may hinder the comparability of financial statements.

It is expected that the implementation of the IFRS for SMEs will create a favorable impact on the financial statements of SMEs. Most of the interviewees indicated that entities would present high-quality, true, reliable and fair financial information and more transparent financial statements as a result of applying IFRS for SMEs. As interviewees highlighted, the main disadvantages and challenges of the IFRS for SMEs identified include cost burden for companies, lack of trained personnel, and interpretation issues.

The findings of this study will be insightful to companies that plan to adopt IFRS for SMEs, as well as regulatory bodies and standard setting authorities in promoting implementation. Although every country has different political, cultural and historical structure that impact their accounting environment, countries adopting IFRS for SMEs may face similar problems to some degree. Timely adoption of IFRS for SMEs is expected to be related with both the magnitude of the change in regulations promoted by transitioning from national GAAP to IFRS for SMEs and strength of the accounting profession within the country (Chand $e t$ al., 2015). Uncertainty about the implementation date and lack of legal backing of IFRS for SMEs are main issues that should be solved by the regulatory bodies. Further, due to ambiguity about the scope of the IFRS for SMEs, there are still discussions, whether or not micro-entities will apply this standard set. The issue 
regarding the scope of IFRS for SMEs also should be considered by standard authorities.

Cost burdens on SMEs are perceived to be the most important disadvantages of moving from local GAAP to IFRS for SMEs including costs of training, dual reporting, collecting financial information, and investing in new accounting software. We suggest a comprehensive assessment of expected costs as well as the benefits of adoption of IFRS for SMEs for Turkish SMEs.

The experience of Turkey revealed that lack of trained personnel is the main challenge for the adoption process of IFRS for SMEs. Since Turkish accounting practitioners are more familiar with rule-based accounting applications, they will face difficulties in applying the principle-based financial reporting standards. In fact, lack of comprehensive training regarding the technical issues of the standard set is the major source of other difficulties, such as wrong applications, incomparable and unreliable financial statements (Ballas et al., 2010). Interviewees highlighted the vital role of universities in training and education of accounting practitioners. In this vein, universities should update their accounting curriculums by addressing financial reporting standards.

Although Turkey became one of earlier adopters of IFRS for SMEs, the adoption process could not be implemented due to various reasons, such as significant differences between current national regulations and proposed standards, lack of trained personnel, concerns about adaptation and application costs, and ambiguity about the scope of the IFRS for SMEs. Therefore, the Turkish case presents the challenges and difficulties that may be encountered by an emerging country during the adoption of a new reporting system.

Our study has a number of limitations. First, the perceptions of professionals prior to implementation process may subject to change by the time. Second, the results are the opinions of Turkish academics, accountants, and auditors. Third, small number of interviews may limit the generalizability of the findings.

\section{References}

Aboagye-Otchere, F. \& Agbeibor, J. (2012) "The international financial reporting standard for Small and Medium-sized Entities (IFRS for SMEs): Suitability for small businesses in Ghana", Journal of Financial Reporting and Accounting, vol. 10, no. 2: 190-214

Akyüz, K.C., Akyüz, İ., Serin, H. \& Cindik, H. (2006) “The financing preferences and capital structure of micro, small and medium sized firm owners in forest products industry in Turkey", Forest Policy and Economics, vol. 8, no. 3: 301-311 
Alali, F. \& Cao, L. (2010) "International financial reporting standards - credible and reliable? An overview", Advances in Accounting, Incorporating Advances in International Accounting, vol. 26, no. 1: 79-86

Albu, C.N. (2013) "How relevant is size for setting the scope of the IFRS for SMEs", Accounting and Management Information Systems, vol. 12, no. 3: 424-439

Albu, C.N., Albu, N. \& Fekete, S. (2010) "The context of the possible IFRS for SMEs implementation in Romania: An exploratory study", Accounting and Management Information Systems, vol. 9, no. 1: 45-71

Albu, C.N., Albu, N., Pali-Pista, S.F., Gîrbină, M.M., Selimoglu Kardes, S., Kovács, D.M., Lukács, J., Mohl, G., Müllerová, L., Paseková, M., Poroy Arsoy, A., Sipahi, B. \& Strouhal, J. (2013) "Implementation of the IFRS for SMEs in emerging economies: Stakeholders perceptions in the Czech Republic, Hungary, Romania and Turkey", Journal of International Financial Management and Accounting, vol. 24, no. 2: 140-175

Al-Mahrouq, M. (2010) "Success factors of small and medium-sized enterprises (SMEs): The case of Jordan", Anadolu University Journal of Sciences, vol. 10, no. 1: 1-16

Alp, A. \& Ustundag, S. (2009) "Financial reporting transformation: The experience of Turkey", Critical Perspectives on Accounting, vol. 20, no. 5: 680-699

Ankarath, N., Mehta, K.J., Ghosh, T.P. \& Alkafaji, Y.A. (2010) Understanding IFRS fundamentals, John Wiley \& Sons Inc., New Jersey, United States

Atik, A. (2010) "SME's views on the adoption and application of "IFRS for SMEs" in Turkey", European Research Studies, vol. 13, no. 4: 19-31

Bahadır, O., Demir, V. \& Öncel, A.G. (2016) "IFRS implementation in Turkey: Benefits and challenges", Accounting and Management Information Systems, vol. 15, no. 1: 5-26

Ballas, A.A., Skoutela, D. \& Tzovas, C.A. (2010) "The relevance of IFRS to an emerging market: Evidence from Greece", Managerial Finance, vol. 36, no. 11: $931-948$

Barker, P. \& Noonan, C. (1996) "Small company compliance with accounting standards: The Irish situation" Dublin City University Business School (working papers), no. 10. available at: http://doras.dcu.ie/2113/1/ DCUBS_Research_Paper_Series_10.pdf (accessed 25 July 2011)

Beck, T. \& Demirguc-Kunt, A. (2006) "Small and medium-size enterprises: Access to finance as a growth constraint", Journal of Banking and Finance, vol. 30, no. 11: 2931-2943

Beck, T., Demirguc-Kunt, A. \& Maksimovic, V. (2008) "Financing patterns around the world: Are small firms different?", Journal of Financial Economics, vol. 89, no. 3: 467-487

Bohusova, H. \& Blaskova, V. (2012) "In what ways are countries which have already adopted IFRS for SMEs different?", Acta Universitatis Agriculturae et Silviculturae Mendelianae Brunensis, vol. 60, no. 2: 37-44 
Bohusova, H., Valouch, P. \& Svoboda, P. (2012) "IFRS for SMEs: What will the implementation of IFRS for SME bring for timber industry?" In Collection of Abstracts from European Accounting Association 35th Annual Congress, Faculty of Economics, Ljubljana, Slovenia: 358-373. available at: http://ftp.mendelu.cz/RePEc/men/wpaper/27_2012.pdf (accessed 11 May 2012)

Bunea, S., Săcărin, M. \& Minu, M. (2012) "Romanian professional accountants' perception on the differential financial reporting for small and mediumsize enterprises", Accounting and Management Information Systems, vol. 11, no. 1: 27-43

Cai, F. \& Wong, H. (2010) "The effect of IFRS adoption on global market integration", International Business and Economics Research Journal, vol. 9, no. 10: 25-34

Chand, P., Patel, A. \& White, M. (2015) "Adopting international financial reporting standards for small and medium-sized enterprises", Australian Accounting Review, vol. 25, no. 2: 139-154

Chand, P., Patel, C. \& Patel, A. (2010) "Interpretation and application of "new" and "complex" international financial reporting standards in Fiji: Implications for convergence of accounting standards", Advances in Accounting, incorporating Advances in International Accounting, vol. 26, no. 2: 280-289

Christie, N., Brozovsky, J. \& Hicks, S. (2010) "Accounting for small businesses: The role of IFRS", CPA Journal, vol. 80, no.7: 40-43

Daly, J.L. (2009) "IFRS for small and medium-sized entities (SMEs)" Executive education, available

http://www.executiveeducationinc.com/file/IFRS\%20for\%20SMEs\%2008 09.pdf (accessed 24 January 2012)

Dumontier, P. \& Raffournier, B. (1998) "Why firms comply voluntarily with IAS: An empirical analysis with Swiss data", Journal of International Financial Management and Accounting, vol. 9, no. 3: 216-245

El-Gazzar, S.M., Finn, P.M. \& Jacob, R. (1999) "An empirical investigation of multinational firms' compliance with international accounting standards", International Journal of Accounting, vol. 34, no. 2: 239-248

Epstein, B.J. \& Jermakowicz, E.K. (2007) "International standards for small and medium-sized entities", CPA Journal, vol. 77, no. 10: 38-40

Eskin, İ. \& Güvemli, B. (2015) "Bir Alabalık Üretim Tesisinde Kobi TFRS'ye İlk Geçiş Uygulaması" [Implementation of the first time transition to TFRS for SMEs in a trout hatchery], Mufad Journal, vol. 66: 89-104.

Fearnley, S. \& Hines, T. (2007) "How IFRS has destabilized financial reporting for UK non-listed entities", Journal of Financial Regulation and Compliance, vol. 15 , no. 4: 394-408

Flower, J. (2005) "The International Accounting Standards Board's proposals for small and medium-sized entities", International Accountant, December: 25 
Georgiou, G. (2010) "The IASB standard-setting process: Participation and perceptions of financial statement users", The British Accounting Review, vol. 42 , no. 2 : $103-118$

Haverty, J.L. (2006) "Are IFRS and U.S. GAAP converging? Some evidence from People's Republic of China companies listed on the New York Stock Exchange", Journal of International Accounting, Auditing and Taxation, vol. 15 , no. 1: 48-71

Hellmann, A., Perera, H. \& Patel, C. (2010) "Contextual issues of the convergence of International Financial Reporting Standards: The case of Germany", Advances in Accounting, Incorporating Advances in International Accounting, vol. 26, no. 1: 108-116

Herman, N. (2010) "IFRS for SMEs: Not for private American companies", CPA Journal, December: 11-12. available at:

http://www.cba.neu.edu/uploadedFiles/Site_Sections/Faculty/Academic_G roups/Accounting_Group/Accounting_Newsletter/Articles/Fall_2010/DecP erspectives.pdf (accessed 25 June 2012)

Hlaciuc, E., Mihalciuc, C.C., Cibotariu, I.S. \& Apetri, A.N. (2009) "Some issues about the transition from U.S. generally accepted accounting principles (GAAP) to international financial reporting standards (IFRS)", Annales Universitatis Series Oeconomica, vol. 11, no. 1: 275-289

Hodgdon, C., Tondkar, R.H., Adhikari, A. \& Harless, D.W. (2009) "Compliance with international financial reporting standards and auditor choice: New evidence on the importance of the statutory audit", International Journal of Accounting, vol. 44 no. 1: 33-55

Hora, J.A., Tondkar, R.H. \& Adhikari, A. (1997) "International accounting standards in capital markets", International Accounting, Auditing, and Taxation, vol. 6, no. 2: 171-190

Iatridis, G. \& Rouvolis, S. (2010) "The post-adoption effects of the implementation of International Financial Reporting Standards in Greece", Journal of International Accounting, Auditing and Taxation, vol. 19, no. 1: 55-65

International Accounting Standards Board (IASB) (2017) "Analysis of the IFRS profiles for the IFRS for SMEs Standard", available at: http://www.ifrs.org/Use-around-the-world/Pages/Analysis-of-SMEprofiles.aspx (accessed 15 January 2017)

Jeanjean, T. \& Stolowy, H. (2008) "Do accounting standards matter? An exploratory analysis of earnings management before and after IFRS adoption", Journal of Accounting Public Policy, vol. 27, no. 6: 480-494

Jones, S. \& Finley, A. (2011) "Have IFRS made a difference to intra-country financial reporting diversity?", British Accounting Review, vol. 43, no. 1: 22-38

Joshi, P.L. \& Ramadhan, S. (2002) "The adoption of international accounting standards by small and closely held companies: Evidence from Bahrain", International Journal of Accounting, vol. 37, no. 4: 429-440 
Kaya, D. \& Koch, M. (2015) "Countries' adoption of the International Financial Reporting Standard for Small and Medium-sized Entities (IFRS for SMEs): Early empirical evidence", Accounting and Business Research, vol. 45, no. 1: 93-120

Kaya, C.T. \& Türegün, N. (2017) "Dünyada KOBİ finansal raporlama uygulamaları ve Türkiye için çıkarımlar: Yerel Finansal Raporlama Çerçevesi'ne bakış" [International assessment of financial reporting practices and interpretations for Turkey: National financial reporting framework], Accounting \& Auditing Review, vol. 50: 97-114.

Kaytmaz Balsari, C. \& Varan, S. (2014) "IFRS implementation and studies in Turkey”, Accounting and Management Information Systems, vol. 13, no. 2: 373-399

K1lıç, M., Uyar, A. \& Ataman, B. (2013) "Perception of the SMEs on the IFRS for SMEs: The case of Turkey", paper presented at International Istanbul Finance Congress, 31st May, Istanbul: 71-81

Kılıç, M., Uyar, A. \& Ataman, B. (2014) "Preparedness for and perception of IFRS for SMEs: Evidence from Turkey", Accounting and Management Information Systems, vol. 13, no. 3: 492-519

Kılıç, M., Uyar, A. \& Ataman, B. (2016) "Preparedness of the entities for the IFRS for SMEs: An emerging country case", Journal of Accounting in Emerging Economies, vol. 6, no. 2: 156-178

Koc Yalkın, Y., Demir, V. \& Demir, D. (2006) "International financial reporting standards and development of financial reporting standards in Turkey", Mali Çözüm Dergisi, vol. 76: 57-73

Köse, Y. (2009) "KOBİ'lerde finansal raporlamanın amaçları ve muhasebe bilgilerinin kullanım düzeyine ilişkin Batı Karadeniz araştırması" [A survey on SME financial reporting aims and the usage level of accounting information in the Western Black Sea Region]", Mufad Journal, vol. 41: 114-121

Maingot, M. \& Zeghal, D. (2006) "Financial reporting of small business entities in Canada", Journal of Small Business Management, vol. 44, no. 4: 513-530

Mantzari, E., Liew, P. \& Mantzaris, I. (2009) "An investigation of the impact of international financial reporting standards (IFRS) on the usefulness of financial reports from internal users' perspective: The case of a Greek medium-sized entity", Proceeding, European Accounting Association Conference, Finland, Tampere

Marwata, M. A. (2006) "The interaction amongst reform drivers in governmental accounting changes: The case of Indonesian local government", Journal of Accounting and Organizational Change, vol. 2, no. 2: 144-163

Maseko, N. \& Manyani, O. (2011) "Accounting practices of SMEs in Zimbabwe: An investigative study of record keeping for performance measurement (a case study of Bindura)", Journal of Accounting and Taxation, vol. 3, no. 8: 171-181 
Murphy, A.B. (1999) "Firm characteristics of Swiss companies that utilize international accounting standards", International Journal of Accounting, vol. 34 , no. 1: 121-131

Müllerová, L., Paseková, M. \& Hyblová, E. (2010) "Harmonization of financial reporting of small and medium-sized enterprises in the Czech Republic", Journal of Modern Accounting and Auditing, vol. 6, no. 1: 55-64

Öztürk, C. (2017) "The role and current status of IFRS in the completion of national accounting rules: Evidence from Turkey", Accounting in Europe, doi: 10.1080/17449480.2017.1304647

Pacter, P. (2009) "An IFRS for private entities", International Journal of Disclosure and Governance, vol. 6, no. 1: 4-20

Perera, D. \& Chand, P. (2015) "Issues in the adoption of international financial reporting standards (IFRS) for small and medium-sized enterprises (SMES)", Advances in Accounting, incorporating Advances in International Accounting, vol. 31, no. 1: 165-178

Poroy Arsoy, A. \& Sipahi, B. (2007) "International financial reporting standards x for small and medium sized entities and the Turkish case", SBF Journal, vol. 62 , no. 4 : $31-48$

Quagli, A. \& Paoloni, P. (2012) "How is the IFRS for SME accepted in the European context? An analysis of the homogeneity among European countries, users and preparers in the European commission questionnaire", Advances in Accounting, incorporating Advances in International Accounting, vol. 26, no. 2: 280-289

Rezaee, Z., Smith, L.M. \& Szendi, J.Z. (2010) "Convergence in accounting standards: Insights from academicians and practitioners", Advances in Accounting, Incorporating Advances in International Accounting, vol. 28, no. 1: $147-156$

Securities and Exchange Commission (SEC) (2000) "International accounting standards" available at: http://www.sec.gov/rules/concept/34-42430.htm (accessed 12 January 2011)

Siam, W.Z. \& Rahahleh, M.Y. (2010) "Implications of applying the international financial reporting standards (IFRSs) for small and medium-sized enterprises on the accounting environment in Jordan", Journal of Accounting, Business and Management, vol. 17, no. 2: 21-33

Stainbank, L. (2008) "The development of financial reporting for SMEs in South Africa: Implications of recent and impending changes", African Journal of Accounting, Economics, Finance and Banking Research, vol. 3, no. 3: 1-17 
Şensoy, N. \& Perek, A.A. (2010) "KOBİler için Uluslararası Finansal Raporlama Standardı ve Vergi Usul Kanunundaki Değerleme esaslarına toplu bakış" [Review of valuation bases in Turkish Tax Procedural Code and international financial reporting standards for small and medium-sized enterprises], Journal of Accounting \& Taxation Studies (JATS), vol. 2: 47-73

TSI (Turkish Statistical Institute) (2015) "Small and medium sized enterprises statistics, 2015", available at: http://www.turkstat.gov.tr/PreHaber Bultenleri.do?id=21864 (accessed 24 March 2017)

Tudor, A.T. \& Mutiu, A. (2008) "Pro and contra opinions regarding a SME accounting standard", Annales Universitatis Apulensis Series Oeconomica, vol. 1, no. 10: 4-16

Uyar, A. \& Güngörmüş, A.H. (2013) "Perceptions and knowledge of accounting professionals on IFRS for SMEs: Evidence from Turkey", Research in Accounting Regulation, vol. 25, no. 1: 77-87

Uyar, A., Kılıç, M. \& Ataman Gökçen, B. (2016) "Compliance with IAS/IFRS and firm characteristics: Evidence from the emerging capital market of Turkey”, Economic Research, vol. 29, no. 1: 148-161

Van Wyk, H.A. \& Rossouw, J. (2009) "IFRS for SMEs in South Africa: A giant leap for accounting, but too big for smaller entities in general", Meditari Accountancy Research, vol. 17, no. 1: 99-116

Walton, P. (2011), An executive guide to IFRS-Content, costs and benefits to business. First edition, John Wiley \& Sons Inc, United Kingdom, Cornwall

Winney, K., Marshall, D., Bender, B. \& Swiger, J. (2010) "Accounting globalization: Roadblocks to IFRS adoption in the United States", Global Review of Accounting and Finance, vol. 1, no. 1: 167-178

Wittsiepe, R. (2008), IFRS for Small and Medium-Sized Enterprises - Structuring the Transition Process, Gabler Publications, Frankfurt, Germany

Yıldız, F. \& Eskin, İ. (2012) "Yeni Türk Ticaret Kanunu'na göre muhasebe bilgi sisteminin değerlendirilmesi" [Evaluation of SME accounting information system under the new Turkish Commercial Code], Organizasyon ve Yönetim Bilimleri Dergisi, vol. 4, no. 2: 61-69

Zeff, S.A. (2007) "Some obstacles to global financial reporting comparability and convergence at a high level of quality", British Accounting Review, vol. 39, no. 4: 290-302

Zeghal, D. \& Mhedhbi, K. (2006) "An analysis of the factors affecting the adoption of international accounting standards by developing countries", International Journal of Accounting, vol. 41, no. 4: 373-386 


\section{Appendix A. List of interviewees}

\begin{tabular}{llll}
\hline Interviewee & Position, experience & Duration & Date \\
\hline Interviewee 1 & $\begin{array}{l}\text { Academician at a public university, 20 } \\
\text { years of academic experience and 15 } \\
\text { Interviewee 2 } 20 \text { min. }\end{array}$ & $\begin{array}{l}\text { Febpruary 12, 2012 } \\
\text { Auditor at an auditing firm, 17 years of } \\
\text { auditing experience and 10 years of } \\
\text { experience on IFRS }\end{array}$ & February 20, 2012 \\
Interviewee 3 & $\begin{array}{l}\text { Academician at a private university, 45 } \\
\text { years of academic experience and 20 } \\
\text { years of experience on IFRS }\end{array}$ & March 13, 2012 \\
Interviewee 4 & $\begin{array}{l}\text { CPA, 15 years of accountant } \\
\text { professional experience and 10 years } \\
\text { of experience on IFRS }\end{array}$ & 45 min. & May 28, 2012 \\
Interviewee 5 & $\begin{array}{l}\text { Auditor, 18 years of auditing } \\
\text { experience, 15 years of experience on } \\
\text { IFRS }\end{array}$ & 30 min. & May 31, 2012 \\
Interviewee 6 & $\begin{array}{l}\text { Auditor, 22 years of auditing } \\
\text { experience, 18 years of experience on } \\
\text { IFRS }\end{array}$ & June 29, 2012 \\
\hline
\end{tabular}

\section{Appendix B. List of interview questions}

1. What are in your opinion the financial reporting characteristics of SMEs?

2. Is, in your opinion, the IFRS for SMEs also applicable to micro-sized, fewer than ten employees, entities?

3. What do you think about the effects of the IFRS for SMEs on other stakeholders, such as banks, credit institutions, etc.?

4. How should be the adoption process of the IFRS for SMEs accelerated?

5. Is there is a need for a separate standard set for SMEs?

6. Do you believe that the IFRS for SMEs was simplified enough for the use of SMEs?

7. What are the advantages of the IFRS for SMEs?

8. Are there any disadvantages of the IFRS for SMEs?

9. What will be the challenges that may be faced by entities during the adoption process of the IFRS for SMEs? 